\title{
Response of black rice (Oryza sativa L Indica.) to organic fertilizer and seedling number on grain yield, amylum, antioxidant, and thiamin hydrochloride contents
}

\author{
Okti Herliana ${ }^{1, *}$, A. H. Saeful Anwar ${ }^{2}$, and Ida Widiyawati ${ }^{1}$ \\ ${ }^{1}$ Jenderal Soedirman University, Faculty of Agriculture, Departement of Agrotechnology, Purwokerto, Central Java, Indonesia
}

\begin{abstract}
This study aimed to investigate the influence of organic fertilizers and seedling numbers each holes of black rice on yield, antioxidant, amylum, and thiamin hydroclorine contents, and to observe the interaction effect between types of organic fertilizers and seedling numbers each hole planting. This study was conducted on rice field in Karanglewas Kidul Village, Karanglewas, Banyumas Regency, Central Java from April until September 2016. The location altitude in this study for about 93 meters above the sea level. The study was arranged by Split Plot Design by the main plot consist with three types of organic fertilizers that was chicken, goat, and cow manures, and the sub plot was consists by seedling number were, three, two, and one seedling by each holes, with three replicates of each combination treatments. The result showed that chicken manure treatment provide the best influences on grain weight per hectare by 5.154 tons, amylum content by $33.86 \%$, anthocyanin content by $275.40 \mathrm{ppm}$, and Thiamin hydrocloride content by $0.056 \mathrm{mg} / 10 \mathrm{~g}$. The three seedling each hole provide the best influences on amylum content by $33.78 \%$, anthocyanin content by $275.18 \mathrm{ppm}$, and thiamine hydrochloride content by $0.058 \mathrm{mg} / 10 \mathrm{~g}$.
\end{abstract}

\section{Introduction}

Rice is a staple food consumed by almost of all Indonesian people. Based on its color, there are three types of rice white, red and black rice. Black rice has higher anthocyanin content than the white one [1]. Black rice is also considered as a source of fibers, minerals and some amino acids required by the body [2]. Black rice contains anthocyanin and antioxidants which are beneficial to our health. Black rice also contains fibers and hemi-cellulose. The study conducted by Mangiri et al. [3] show that black rice has fiber content by $0.8 \%$, vitamin $C$ by $0.6 \mathrm{mg}$ and vitamin $\mathrm{E}$ by $31.6 \mathrm{mg}$. The dominant components of black rice are carbohydrate by $64.98 \%$, total protein content by $15.41 \%$, fat content by $4.23 \%$, minerals by $2.04 \%$, and water content $13,34 \%$ [4].

Rice plants require the nourishment substance N, P and $\mathrm{K}$ to support the growth and quality of the rice produced. The nutrients serve as the nutrient sources for the plant growth, the formation of saplings as well as chlorophyll for assimilation processes, which eventually produce amylum and determine the quality of rice, such as amylum, anthocyanin and vitamin B contained in rice grains. Thus, to obtain grains with high quantity and good quality, then the plants are required to be given a complete nutrients [5]. Nutrient sources may be obtained from both anorganic and organic fertilizers. In organic farming system, the source of nutrients used may derived from the agricultural and livestock wastes, such as manure, green manure, agricultural waste, biological fertilizer, and household waste [6].

The application of organic fertilizers can maximally absorbed by the black rice plants, affected by several factors, such as plant population level. The plant population density is determined by the planting space and seedling number each holes. Indonesian Farmers usually grow their rice using a large number of seedlings. It is considered inefficient in terms of seedling availability and competition among plants that gave an influence on plant growth and production. The utilization of young seedling and one plant may support better for growth [7].

The number of seedlings per planting hole may influence the number of productive saplings and weight of 1000 grains, on the planting of 3 seedlings per planting hole on a plot of $3 \mathrm{~m}^{2}$ and with the urea dosage of $120 \mathrm{~g} / \mathrm{plot}, \mathrm{SP}-3660 \mathrm{~g} / \mathrm{plot}$ and KCL $60 \mathrm{~g} / \mathrm{plot}$ shows the production of dry milled grains per plot by $2.18 \mathrm{~kg}$ or equivalent to GKG 7.2 tons/ha [8]. Christanto et al. [9] argue that the upland rice (gogo paddy) conducted with SRI method and then treated using a variation of planting spaces may influence the maximum sapling number and leaf area index. The treatment conducted using seedlings per planting hole may influence the weight of 1000 oven- dry grains, number of grain per panicle, oven-dry grain weight harvested per hectare, oven-dry grain weight per hectare and harvest index.

The utilization of organic fertilizers and the seedling number per planting hole has not been frequently applied 
to the cultivation of black rice plants. Thus, it is considered necessary to conduct a study in order to investigate the best organic fertilizer and most optimum seedling number per planting hole for the black rice plant.

\section{Material and methods}

This study was conducted in the rice fields of Karanglewas Kidul Village, Karanglewas Sub-district, Banyumas Regency, Central Java, from April to September 2016. The average daily temperature of the research area is $29.3{ }^{\circ} \mathrm{C}$ with humidity between 60 to $99 \%$. The research location altitude is 93 meters above the sea level. The materials used in this study include black rice seedlings and the manures of chicken, goat, and cow. Supporting tools used in this research include water gauge, soil moisture meter, lux meter, thermo hygrometer, seed separation and counter, altimeter, hoe, scissor, hand sprayer, hand counter, cutter, millimeters blocks, weigh balance and ovens.

This study used Split plot design with three replications. This is considered as a field study with $2 \mathrm{x}$ 3 meter plot system with the main plot in the form of organic fertilizers, covering chicken manure (P1), goat manure (P2), cow manure (P3), while the sub-plot is the number of seedlings per planting hole, covering one seedling per planting hole (B1), two seedlings per planting hole (B2), and three seedlings per planting hole (B3).

The variables observed are plant growth rate, net assimilation rate, leaf area index, chlorophyll content of $\mathrm{a}$ and $\mathrm{b}$, amylum, anthocyanin, thiamin hydrochloride, and grain weight per hectare. Chlorophyll content was analyzed using spectrofotometry on $665 \mathrm{~nm}$ spectrum, Amylum content of rice was analyzed using the method colorimetric iodide [10], antocyanin was analyzed by Shi method [11], and Thyamine hydrochloride was analyzed by Sudarmaji method [12]. Data analysis is conducted with analysis of varians, if the result is significant among the observed treatments, it will be followed by DMRT (Duncan Multiple Range Test) at the level 5\%.

\section{Result and discussion}

The analysis of varians results of various treatments conducted with several fertilizer types and number of seedling per planting hole presented in Table 1 show that the treatments conducted with several types of organic fertilizers influence the variables of chlorophyll a, grain weight per hectare, amylum content, anthocyanin and thiamin hydrochloride. Meanwhile, the treatments conducted with several numbers of seedlings per planting hole influence the variables of plant growth rate, leaf area index, the content of amylum, anthocyanin and thiamin hydrochloride. However, there is no significant interaction between those two treatments to the observed variables.
Table 1. The results of various observations on the yield and quality of black rice

\begin{tabular}{llll}
\hline \multirow{2}{*}{ Variabel } & \multicolumn{3}{c}{ Treatment } \\
\cline { 2 - 4 } & $\mathrm{P}$ & $\mathrm{B}$ & $\mathrm{PxB}$ \\
\hline Plant Growth rate & $\mathrm{ns}$ & $\mathrm{s}$ & $\mathrm{ns}$ \\
Leaf area index & $\mathrm{ns}$ & $\mathrm{s}$ & $\mathrm{ns}$ \\
Clorofil b & $\mathrm{ns}$ & $\mathrm{ns}$ & $\mathrm{ns}$ \\
Clorofil a & $\mathrm{s}$ & $\mathrm{ns}$ & $\mathrm{ns}$ \\
Amilum & $\mathrm{vs}$ & $\mathrm{vs}$ & $\mathrm{ns}$ \\
Antosianin & $\mathrm{vs}$ & $\mathrm{vs}$ & $\mathrm{ns}$ \\
Thiamin Hidroklorida & $\mathrm{vs}$ & $\mathrm{vs}$ & $\mathrm{ns}$ \\
\multicolumn{1}{c}{ Grain weight (ton hectar ${ }^{-1}$ ) } & $\mathrm{s}$ & $\mathrm{ns}$ & $\mathrm{ns}$ \\
\hline $\mathrm{P} \quad:$ Organic fertilizer & & & \\
B : Seeding number & & & \\
PxB : Interaction between two treatments \\
ns : non significant
\end{tabular}

\subsection{Influence of organic fertilizer to graind yield and black rice quality}

The black rice plant has various responses to the application of organic fertilizers. The results of further Duncan test are shown in Table 2.

Table 2. The average data on the influence of treatments conducted with several organic fertilizer types on the black rice yield

\begin{tabular}{|c|c|c|c|}
\hline \multirow{2}{*}{ Variable } & \multicolumn{3}{|c|}{ Type of Organic Frertiliz } \\
\hline & P1 & $\mathrm{P} 2$ & P3 \\
\hline KK a & $2,11 \mathrm{a}$ & $2,11 \mathrm{a}$ & $1,90 \mathrm{~b}$ \\
\hline Am & $33,86 \mathrm{a}$ & $32,59 \mathrm{~b}$ & $32,13 \mathrm{c}$ \\
\hline An & $275,40 \mathrm{a}$ & $265,39 \mathrm{~b}$ & $263,30 \mathrm{c}$ \\
\hline $\mathrm{TH}$ & $0,056 \mathrm{a}$ & $0,054 \mathrm{~b}$ & $0,050 \mathrm{c}$ \\
\hline WGH & 5,154 a & $4,271 \mathrm{~b}$ & $3,933 \mathrm{~b}$ \\
\hline$: \mathrm{C}$ & \multicolumn{3}{|c|}{ : Chiken manure } \\
\hline : $\mathrm{C}$ & \multicolumn{3}{|c|}{ : Goat Manure } \\
\hline : C & \multicolumn{3}{|c|}{ : Cow manure, Clorofil a on $665 \mathrm{~nm}$ spectrum, } \\
\hline Am & \multicolumn{3}{|c|}{ : Amilum content $(\%)$} \\
\hline An & \multicolumn{3}{|c|}{ : Antocyanin (ppm) } \\
\hline $\mathrm{TH} \quad: \mathrm{T}$ & \multicolumn{3}{|c|}{ : Thiamin Hidroklorida (mg/10 g sample) } \\
\hline WGH : $\begin{aligned} & \mathrm{V} \\
& \mathrm{c} \\
& \mathrm{c}\end{aligned}$ & \multicolumn{3}{|c|}{$\begin{array}{l}\text { : Wight Grain hectar }{ }^{-1} \text { (Tons). Numbers followed by } \\
\text { different letter at each column are significantly } \\
\text { different at } \mathrm{P}=0.05\end{array}$} \\
\hline
\end{tabular}

The influence of treatments conducted with several organic fertilizers on black rice yield and quality in Table 2 shows that the treatments conducted with several types of manures influence the variables of chlorophyll, amylum, anthocyanin and thiamin hydrochloride content as well as the grain weight per hectare. The best treatment is characterized by a notation, the second best treatment is indicated by $b$ notation, and that is not quite good is characterized by c notation. The variable of chlorophyll content has the best result at treatment P1 
(chicken manure) and the second best at P2 (goat manure) by 2.11 , while last one at $\mathrm{P} 3$ (cow manure) by 1.90. The variable of amylum content has the best result at treatment $\mathrm{P} 1$ by $33.86 \%$, the second best at $\mathrm{P} 2$ by $32.59 \%$ and the last one is at $\mathrm{P} 3$ by $32.13 \%$. In the variable of anthocyanin content, the best result is at treatment $\mathrm{P} 1$ by $275.40 \mathrm{ppm}$, the second best at $\mathrm{P} 2$ by $265.39 \mathrm{ppm}$ and the last one at P3 by $263.30 \mathrm{ppm}$. The variable of thiamin hydrochloride content, the best result is at treatment $\mathrm{P} 1$ by $0.056 \mathrm{mg} / 10 \mathrm{~g}$ material, the second best at treatment P2 by $0.054 \mathrm{mg} / 10 \mathrm{~g}$ material and the last one at $\mathrm{P} 3$ by $0.050 \mathrm{mg} / 10 \mathrm{~g}$ material. lastly, the variable of grain weight per hectare, the best result is at $\mathrm{P} 1$ by $5154.67 \mathrm{~kg} / \mathrm{ha}$, the second best is at $\mathrm{P} 2$ by 4271.33 and the last one at P3 by $3933.26 \mathrm{~kg} / \mathrm{ha}$.

The manures influence the rice plant chlorophyll content. Damanik et al. [13] explain that the administration of nitrogen directly influences the carbohydrate synthesis in the plant cells. Nitrogen has also the role as a chlorophyll composer causing the leaves have the green color. Hartanto and Maya [14] who conduct a study on Ciherang rice variety explain that time for the chicken manure application influences the length of the plant roots. However, it is unknown whether the types of manure may also influence the length of the rice plant roots or not.

Based on the results of study conducted by Purnomo et al, [15], the addition of vermicompost/ cow manure (5 tons/ha) + inorganic fertilizer (urea $226 \mathrm{~kg} / \mathrm{ha}+$ phonska $360 \mathrm{~kg} / \mathrm{ha}$ ) with the planting of three seedlings per planting hole may produce the highest rice amylum content. Hardjowigeno [16], explains that the addition of organic material derived from vermicompost or cow manure on the rice field soil plays an important role in increasing the availability of $\mathrm{N}$ nutrients in the soil. The decomposition result of organic materials on waterflooded soil like the common rice fields is, one of them, in the form of $\mathrm{NH}_{4}$ which may be directly utilized by the plants. Application of organic fertilizer also influenced antocyanin content on grape fruit, that the high doses 30 $\mathrm{t} / \mathrm{ha}$ can increase the antocyanin content $12 \%$ higher than $20 \mathrm{t} / \mathrm{ha}[17]$.

The treatments of manures influence the components of the rice yield which is in accordance with research conducted by Bachtiar et al. [18] stating that the administration of SP-36 $100 \%+$ manure $5 \mathrm{t} / \mathrm{ha}$ on the soil with the manure $20 \mathrm{t} / \mathrm{ha}$ may produce the dry grain weight by $648 \mathrm{~g}$ per the treatment plot which is almost twice bigger than that in control plot by only 344 grams. Organic fertilizer with inorganic fertilizer increased the fertilizer use efficiency and improved the physical and chemical properties of soil and it would be a reason towards increased yield [19].

\subsection{Influence of seeding number to yield and quality of black rice}

The influence of treatments conducted with the number of seedlings per planting hole on the black rice yield and quality is presented in Table 3 . The treatments conducted with the number of seedlings per planting hole influence the variables of plant growth rate, leaf area index, the content of amylum, anthocyanin and thiamin hydrochloride.

Table 3. The average data on the influence of treatments conducted with number of seedlings per planting hole on yield and quality of black rice.

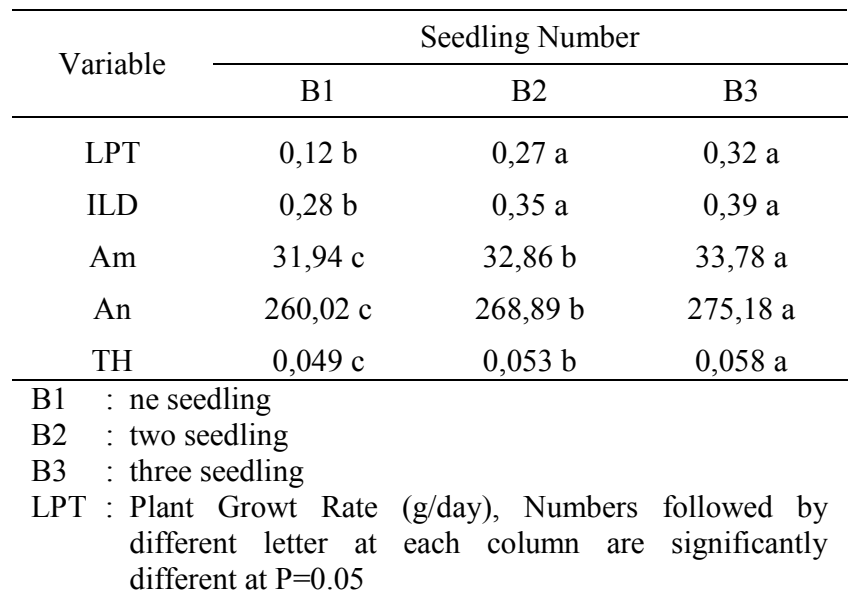

The best result for the plant growth rate variable is at treatment B3 (3 seedlings per planting hole) and the second best at treatment B2 (2 seedlings per planting hole) respectively by $0.32 \mathrm{~g} /$ day and $0.27 \mathrm{~g} / \mathrm{day}$, while the last one at treatment B1 (1 seedling per planting hole) by $0.12 \mathrm{~g} /$ day. The best result for the leaf area index variable is at treatment B3 and the second best at treatment B2 respectively by 0.39 and 0.35 , while the last one at treatment $\mathrm{B} 1$ by 0.28 . The best result for amylum content variable is at treatment B3 by $33.78 \%$, the second best at treatment $\mathrm{B} 2$ by $32.86 \%$ and the last one at B1 by $31.94 \%$. The best result for anthocyanin content variable is at treatment B3 by $275.18 \mathrm{ppm}$, the second best at treatment B2 by $268.89 \mathrm{ppm}$ and the last one at treatment B1 by $260.02 \mathrm{ppm}$. Lastly, The best result for thiamin hydrochloride content variable is at treatment $\mathrm{B} 3$ by $0.058 \mathrm{mg} / 10 \mathrm{~g}$ material, followed by treatment B2 $0.053 \mathrm{mg} / 10 \mathrm{~g}$ material and the last one at treatment B1 by $0.049 \mathrm{mg} / 10 \mathrm{~g}$ material.

Number of seedlings hill- 1 is an important factor for successful rice production because it influences tiller population unit-1 area, which ultimately influence the yield [20]. Optimum number of seedlings hill-1 ensures proper crop establishment. Generally if single seedling is used than there is a chance for missing hills. On the other hand, if more than optimum seedlings hill-1 is used then there will be misuse of seedlings resulting excess use of seeds. But in these research the best result of all variable is three seedling hill ${ }^{-1}$ because used of single and second seedling is Seedling vigor contributes to successive tillering, yield and quality of transplanted rice. Growth and production of rice depend on timely cultivation and growth duration of cultivar which is affected by the number of seedlings hill-1 [21].

Hutagaol [22] explains that the treatments conducted with the number of seedlings per different planting hole for the upland rice plants produce vegetative variables with the best influence on the plant height and number of saplings at the administration of 4 seedlings. Wangiyana 
et al. [23] further explain that the planting of 3 seedlings per planting hole may result in more productive yield. The utilization of 3 seedlings per planting hole produces higher number of leaves, clumps and dry rice straw weight than the planting utilizing 1 and 2 seedlings per planting hole. Similarly, Zulhendi [24] also explains that the higher the number of seedlings per planting hole may result in higher number of saplings. Meanwhile, the higher the number of saplings may correlate more with the value of leaf area index that the value of ILD may also increase. The higher value of ILD, the wider the photosynthesis area and the photosynhtate produced. Local black rice varieties have a less adaptive ability to grow so that the use of the number of seeds 3 per hole better and support the development of tillers, panicles and grain. Grain quality is also determined by the resulting photosynthate.

According to Purnomo et al. [15], the process of photosynthesis in plants greatly influences the amylum content since the result of photosynthesis process is stored in the forms of carbohydrate and energy. The declining photosynthesis process may lead to the reduced photosynthesis result. This photosynthate is then stored in the forms of carbohydrate in stems and grains. Thus, the better the process of photosynthesis in plants the higher the formation of carbohydrates.

In this study, the highest thiamin content in black rice is $0.058 \mathrm{mg} / 10 \mathrm{~g}$ material or about $5.8 \mathrm{mg} / \mathrm{kg}$ material. This is in accordance with the research conducted by Laksmiwati et al. [25] stating that the thiamin content in black rice after cooking is about $5.3 \mathrm{mg} / \mathrm{kg}$, extremely different from that of white rice which is only about 2.6 $\mathrm{mg} / \mathrm{kg}$.

\section{Conclusions}

The results showed that chicken manure treatment has gave the best influences of grain weight per hectare, amylum, anthocyanin and thiamin hydrochloride contents. In facts, 3 seedlings per planting hole treatment has gave the best influence of plant growth rate, leaf area index, anthocyanin, amylum, and thiamin hydrochloride contents.

Acknowledgements The authors would like to thank to the Research and Public Services Institution (LPPM) of Jenderal Soedirman University (Unsoed), Indonesia, for funding this study.

\section{References}

1. Q. Wang, P. Han, M. Zhang, M. Xia, H. Zhu, J. Ma, M. Hou, Z. Tang, W. Ling, Asia Pac J. Clin Nutr 16, 295 (2007)

2. M. Hiomori, E. Koh, A.E Mitchell, J. Agric. Food Chem. 57, 1908 (2009)

3. J. Mangiri, N. Maluyu, S.E.S Kawengian, eBiomedik, 4 (2016)

4. S. Hartati, J. Food and Nutrient, 4, 57 (2012)
5. Rasam, A. Rasna, Pemupukan pada Tanaman Padi (Balai Besar Penelitian Tanaman Padi, Indonesia, 2015)

6. E.A. Stockdale, N.H. Lampkin, R. Keatinge, E.K.M. Lennartsson, D.W. Macdonald, S. Padel, F.H. Tattersall, M.S Wolfe, C.A. Watson, Adv. Agron. 70, 261 (2001)

7. A.H. Pinem, A. Barus, H. Chairani, Agroteknologi 1, 921 (2013)

8. J. Susilo, Ardian, E. Ariani, Jom Faperta 2, 1 (2015)

9. H. Christanto, I.G.M.S. Agung, J. Bumi Lestari 14, 1 (2014)

10. B.O. Juliano, Cer. Sci. Today 16, 334 (1971)

11. Z. Shi, M. Lin, F.J. Prancis., J Food Sci. 57, 758 (1992)

12. S. Sudarmaji, B. Haryono, Suhardi, Prosedur Analisis untuk Bahan Pangan dan Gizi (Gadjah Mada University, Yogyakarta, Indonesia, 1997)

13. M. Damanik ,M.B. Bachtiar, E.H. Fauzi, Kesuburan Tanah dan Pemupukan (USU Press, Medan, Indonesia, 2011)

14. M. Hartanto, M. Melati, Bul. Agrohorti 1, 9 (2013)

15. B.B. Purnomo, S. Jauhari, H. Sri, Kajian Penambahan Vermikompos dan Pupuk Anorganik Terhadap Kualitas dan Hasil Tanaman Padi (Oryza sativa L.) di Lahan Sawah Palur Sukoharjo (Sebelas Maret University, Surakarta, Indonesia, 2011)

16. S. Hardjowigeno, Ilmu Tanah (Akademika Presindo, Jakarta, Indonesia, 2005)

17. K. Seung-Heui, K. Seon-Kyu, J. Plant Biotech. 1, 7 (2002)

18. T. Bachtiar, S.H. Waluyo, S.H. Syaukat, J. Ilmiah Aplikasi Isotop dan Radiasi 9, 151 (2013)

19. T.P. Gangmei, P.J. George, J. Pharma. Phytochem. 6, 550 (2017)

20. M.O. Farouk, M.A. Rahman, M.A. Hasan. Int. J. Suatain. Crop. Prod 4, 58 (2009)

21. A. Mishra, V.M Salokhe, Exptl. Agric. 44, 365 (2008)

22. H.P. Hutagaol, J. Ginting, S. Ginting, Agroteknologi 1, 467 (2013)

23. W. Wangiyana, Z. Laiwan, Sanisah, Crop Agro 2, 70 (2009)

24. Zulhendi, Pengaruh Jumlah Bibit per Titik Tanam dan Umur Bibit Terhadap Pertumbuhan dan Hasil Padi Sawah Dalam Sistem Intensifikasi Padi (SRI) (Andalas University, Sumatra Barat, Indonesia, 2005)

25. A.A.I.A.M. Laksmiwati, K. Ratnawati, N.W. Agustini, J. Chemistry 6, 47 (2012) 